\title{
PENERAPAN SISTEM IMUNISASI PADA PUSKESMAS DI DESA LENGKONG KULON (PUSKESMAS PAGEDANGAN)
}

\author{
Friska Natalia ${ }^{1}$, Ririn Ikana Desanti ${ }^{2}$, Ferry Vincenttius Ferdinand ${ }^{3}$ \\ ${ }^{1}$ Universitas Multimedia Nusantara \\ ${ }^{2}$ Universitas Multimedia Nusantara \\ ${ }^{3}$ Universitas Pelita Harapan
}

friska.natalia@umn.ac.id, ririn.desanti@umn.ac.id, ferry.vincenttius@uph.edu

\begin{abstract}
Abstrak
Pemerintah Indonesia telah menggiatkan upaya untuk memenuhi target Imunisasi Dasar Lengkap (IDL) di Indonesia. Salah satu upaya yang dijalankan yaitu penyuluhan kepada para ibu untuk mengedukasi mereka apa pentingnya imunisasi kepada bayi, sehingga dapat mendorong para ibu untuk membawa anaknya mendapatkan imunisasi, terutama 5 Imunisasi Dasar Lengkap. Kementrian Kesehatan Indonesia juga mengupayakan untuk menjamin akses pelayanan di daerah yang sulit dijangkau dengan cara bekerja sama dengan lintas sektor lainnya, menjamin ketersediaan vaksin, dan pelatihan kepada petugas kesehatan. Urgensi permasalahan prioritas merupakan salah satu bentuk Upaya Kesehatan Bersumber Daya Masyarakat (UKBM) yang dikelola dan diselenggarakan dari, oleh, untuk dan bersama masyarakat dalam penyelenggaraan pembangunan kesehatan, guna memberdayakan masyarakat dan memberikan kemudahan kepada masyarakat dalam memperoleh pelayanan kesehatan dasar untuk mempercepat penurunan angka kematian bayi dan balita.

Objek yang akan diambil adalah Desa Lengkong Kulon, lokasinya di pesisir sungai cisadane, Desa Lengkong Kulon Kecamatan Pagedangan - Kabupaten Tangerang. Permasalahan yang terjadi adalah puskesmas pagedangan di Desa Lengkong Kulon ini belum memiliki sistem imunisasi online sebagai fasilitas kesehatan berbasis web yang dapat mengingatkan para ibu untuk mengimunisasi anaknya tepat waktu. Selain itu proses penyebaran informasi mengenai ketersediaan vaksin di Puskesmas masih belum tersistem dan penghitungan stok yang dibutuhkan masih menggunakan perkiraan secara manual.

Program penerapan sistem imunisasi pada puskesmas pagedangan ini bertujuan untuk menerapkan sistem imunisasi online berbasis web (SISMUNDU) yang dapat membantu para bayi mendapatkan imunisasi secara tepat waktu dengan cara mengirimkan pengingat (reminder) kepada pihak Puskesmas dan pihak ibu, sehingga kedua pihak tersebut dapat mempersiapkan hal-hal yang diperlukan untuk memenuhi imunisasi, terutama Imunisasi Dasar Lengkap. Selain itu sistem imunisasi ini juga dapat membantu Puskesmas mempersiapkan vaksin yang akan dibutuhkan pada waktu tertentu. Kegiatan akan dilakukan pada beberapa tahap meliputi (1) survey lokasi; (2) persiapan lokasi; (3) pengadaan sarana dan prasarana; (4) perekrutan peserta dan asisten trainer; (5) perekrutan koordinator lapangan; (6) pelaksanaan pengabdian (pelatihan, produksi, promosi dan distribusi); (7) evaluasi hasil produksi, promosi dan distribusi; dan (8) penulisan laporan PKM.
\end{abstract}

Kata Kunci: sistem imunisasi, sistem berbasis web, penerapan sistem 


\section{PENDAHULUAN}

Pemerintah Indonesia sudah menggiatkan upaya untuk memenuhi target Imunisasi Dasar Lengkap (IDL) di Indonesia. Salah satu upaya yang dijalankan yaitu penyuluhan kepada para ibu untuk mengedukasi mereka apa pentingnya imunisasi kepada bayi, sehingga dapat mendorong para ibu untuk membawa anaknya mendapatkan imunisasi, terutama 5 Imunisasi Dasar Lengkap yaitu Hepatitis B, BCG, Polio, DPT, dan Campak. Kementrian Kesehatan Indonesia juga mengupayakan untuk menjamin akses pelayanan di daerah yang sulit dijangkau dengan bekerja sama dengan lintas sektor lainnya, menjamin ketersediaan vaksin, dan pelatihan kepada petugas kesehatan.

Urgensi permasalahan prioritas adalah sebagai salah satu bentuk Upaya Kesehatan Bersumber Daya Masyarakat (UKBM) yang dikelola dan diselenggarakan dari, oleh, untuk dan bersama masyarakat dalam penyelenggaraan pembangunan kesehatan, guna memberdayakan masyarakat dan memberikan kemudahan kepada masyarakat dalam memperoleh pelayanan kesehatan dasar untuk mempercepat penurunan angka kematian bayi dan balita. Objek yang akan diambil adalah Desa Lengkong Kulon, lokasinya di pesisir sungai cisadane, Desa Lengkong Kulon Kecamatan Pagedangan - Kabupaten Tangerang seperti yang terlihat pada peta Gambar 1 .

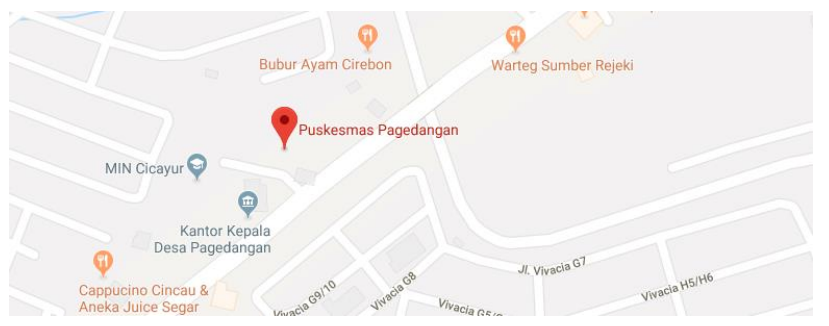

Gambar 1. Peta Lokasi Puskesmas Pagedangan

Permasalahan yang ada di Desa Lengkong Kulon ada tiga, yaitu: (1) Puskesmas yang ada di Desa Lengkong Kulon belum memiliki sistem imunisasi online sebagai fasilitas kesehatan berbasis web yang dapat mengingatkan para ibu untuk mengimunisasi anaknya tepat waktu. (2) Proses penyebaran informasi mengenai ketersediaan vaksin di Puskesmas masih belum tersistematis dengan baik. (3) Di Puskesmas stok vaksin sering sekali kosong karena cara penghitungan stok yang dibutuhkan masih menggunakan perkiraan secara manual.

Program penerapan sistem imunisasi pada puskesmas yang ada di Desa Lengkong Kulon bertujuan untuk menerapkan sistem imunisasi online berbasis web (SISMUNDU) yang dapat membantu para bayi mendapatkan imunisasi secara tepat waktu dengan mengirimkan pengingat (reminder) kepada pihak Puskesmas dan pihak ibu, sehingga kedua pihak tersebut dapat mempersiapkan hal-hal yang diperlukan untuk memenuhi imunisasi, terutama Imunisasi Dasar Lengkap. Tujuan dari kegiatan penerapan sistem imunisasi di Desa Lengkong Kulon adalah menerapkan sebuah sistem imunisasi online berbasis web pada Puskesmas yang dapat membantu para ibu mendapatkan imunisasi anaknya tepat waktu dimana sistem dapat memberikan info kepada para ibu mengenai stok vaksin yang kosong dan/atau tersedia. Selain itu sistem imunisasi ini juga dapat membantu Puskesmas mempersiapkan vaksin yang akan dibutuhkan pada waktu tertentu.

\section{METODE}

Tahapan metode pelaksanaan penerapan sistem imunisasi di Puskesmas Pagedangan Desa Lengkong Kulon yang berlangsung mulai dari bulan Januari hingga Desember 2019 adalah seperti yang terlihat pada gambar 2 .

\section{Pengumpulan Data}

Pengumpulan data dilakukan di bulan Januari 2019 dengan menggunakan 3 metode yaitu (1) wawancara: untuk mengetahui fitur- fitur apa saja yang dibutuhkan, dan jenis jenis imunisasi apa saja yang dilayani dalam Puskesmas tersebut; (2) kuesioner: menyebarkan kuesioner yang ditujukan kepada para ibu yang ada di Desa Lengkong Kulon untuk mengetahui apakah sistem ini akan membantu para ibu, dan mengetahui sebab sebab keterlambatan anaknya mendapatkan imunisasi dari keterangan para ibu; dan (3) observasi: melakukan metode observasi Puskesman ketika Puskesmas sedang

$$
\text { Kesehatan } 471
$$


melayani balita yang akan melakukan imunisasi. Observasi dilakukan untuk mencari hal hal yang belum mungkin belum diungkapkan dalam proses pengumpulan data lainya, baik oleh dokter maupun para ibu.

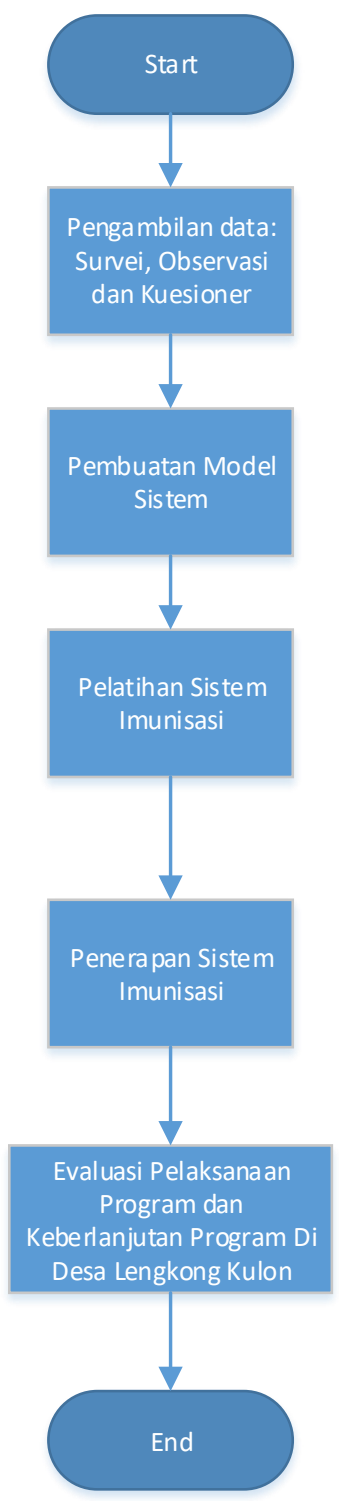

Gambar 2. Tahapan Metode PKM

\section{Pembuatan Model Sistem}

Proses pembuatan model sistem dilakukan mulai dari Bulan Februari hingga Mei 2019. Data yang didapatkan dari hasil pengumpulan data berupa kebutuhan sistem (requirement) yang berasal dari wawancara dan hasil kuesioner. Requirement ini kemudian akan dimasukkan ke dalam metode RAD untuk dijadikan user design sehingga dapat dilanjutkan ke tahap pembuatan sistem (Construction). Selama tahap pembuatan sistem, user design bisa berubah menyesuaikan dengan kebutuhan. Jika sistem sudah diterima oleh user, maka akan berlanjut ke tahap cut over, dimana pada tahap ini sistem akan dipegang oleh user sepenuhnya. Tahap user design akan membuat pemodelan aplikasi dengan menggunakan Unified Modeling Language (UML) untuk menggambarkan proses yang akan berjalan dalam aplikasi, dan relasi database dalam bentuk Entity Relationship Diagram (ERD) untuk menggambarkan relasi antar tabel di database. Hasil akhir dari UML adalah use case, activity diagram, dan sequence diagram. Pada tahap construction, setiap sequence diagram akan dibuat menjadi aplikasi berbasis web dengan menggunakan bahasa pemrograman PHP dengan framework Codeigniter versi 2.2.6 dan sistem basis data MySQL. Untuk menciptakan halaman website yang dinamis, akan digunakan Ajax.

\section{Pelatihan Sistem}

Pelatihan Sistem Imunisasi (SISMUNDU) pada Puskesmas Desa Lengkong Kulon dilakukan pada Bulan Juni di Universitas Multimedia Nusantara. Sistem imunisasi ini berbasis web, sehingga pada pelatihan dibutuhkan akses internet dan peralatan lainnya untuk memastikan Ibu-Ibu dan pihak Puskesmas dapat memakai sistem imunisasi online ini.

\section{Teknik Penerapan Sistem}

Penerapan Sistem Imunisasi (SISMUNDU) pada Puskesmas Desa Lengkong Kulon akan dilakukan secara online. Sistem imunisasi ini berbasis web, sehingga mendukung kemudahan user dalam mengakses sistem. Sistem ini juga akan menggunakan MySQL Database sebagai media penyimpanan data, sehingga data yang tersimpan dapat diakses kembali di kemudian hari. 
Hosting akan dilakukan untuk pihak Puskesmas menggunakan sistem ini dan Ibu-Ibu di Desa Lengkong Kulon dapat langsung memakainya.

\section{HASIL DAN PEMBAHASAN}

\section{Pelaksanaan Kegiatan Sosialisasi}

Pelaksanaan kegiatan pelatihan PKM ini terbagi menjadi 3 kegiatan utama yaitu: (1) Kegiatan sebelum acara yang terdiri dari dua kegiatan, yaitu (a) kunjungan ke Puskesmas Pagedangan di Desa Lengkong Kulon yang dilaksanakan pada tanggal 2 Mei 2019 seperti yang terlihat pada gambar 3dan (b) persiapan menginstall aplikasi "SISMUNDU" dilaksanakan pada tanggal 24 Juni 2019. Kunjungan dilakukan oleh panitia pelaksana acara dengan menemui kepala Puskesmas Pagedangan. Sedangkan pada persiapan menginstall aplikasi "SISMUNDU" para panitia melakukan pengecekan pada ruang lab dan komputer yang akan digunakan sebagai sarana sosialisasi aplikasi "SISMUNDU", kegiatan ini seperti yang terlihat pada gambar 4; (2) Kegiatan pelaksanaan acara terdiri dari dua sesi pelaksanaan, yaitu pada sesi I dilaksanakan pada tanggal 26 Juni 2019 yang dihadiri oleh kepala puskesmas, staff puskesmas, Dinas Kesehatan, dan bapak Winarno selaku pelindung dari kegiatan sosialisasi ini dengan total peserta 19 orang. Pada sesi II dilaksanakan pada tanggal 27 Juni 2019 yang dihadiri oleh kader posyandu dan ibu-ibu Desa Lengkong Kulon dengan total peserta 25 orang. Materi dalam kegiatan pelaksanaan acara ini adalah memberikan pelatihan dalam penggunaan aplikasi imunisasi "SISMUNDU", kegiatan ini seperti yang terlihat pada gambar 5; dan (3) Kegiatan setelah acara terdiri dari dua kegiatan, yaitu pada kegiatan pertama dilaksanakan pada tanggal 7 Agustus 2019 yang membahas mengenai pembuatan laporan, membahas kemajuan laporan pertanggungjawaban dan pelaksaan post implementation. Kegiatan kedua yaitu post implementation dilaksanakan bulan September 2019 dengan mengunjungi kembali Puskesmas Pagedangan di Desa Lengkong Kulon dan melakukan review terhadap sistem yang sudah diterapkan.
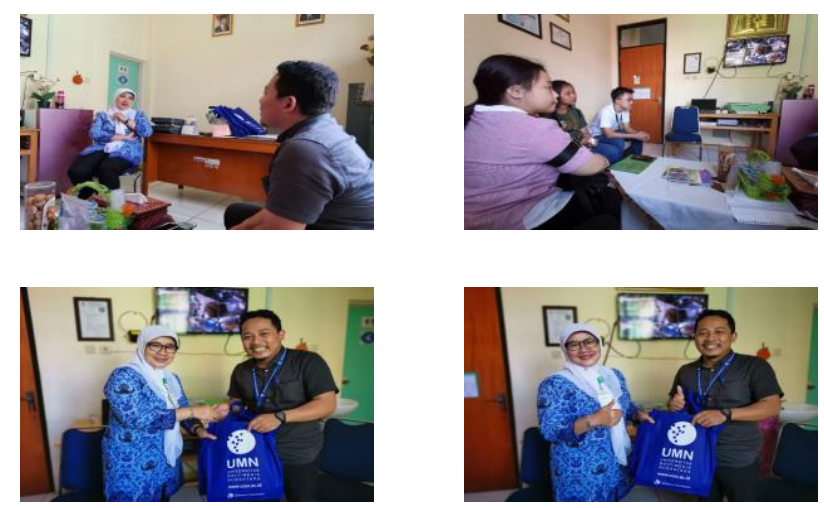

Gambar 3. Kunjungan ke Puskesmas Pagedangan
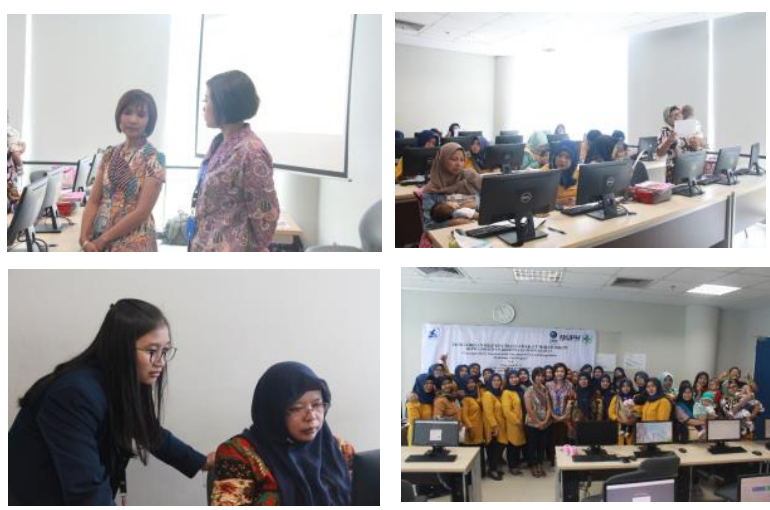

Gambar 4. Persiapan Menginstall Sistem
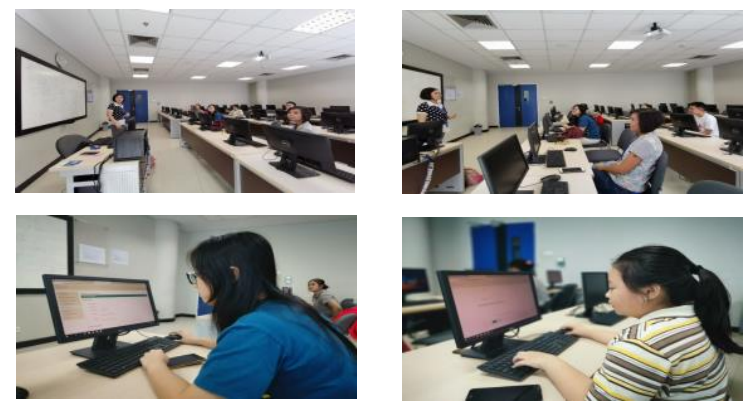

Gambar 5. Sosialisasi Sismundu

\section{Evaluasi Pelaksanaan Program}

Kesehatan 
Berdasarkan hasil kuesioner evaluasi kegiatan terlihat bahwa pihak Puskesmas dan juga masyarakat cukup antusias dengan kegiatan ini dan merasa bahwa sistem ini dapat membantu mereka.

Dari kegiatan post implementation terdapat beberapa masukan terkait fitur-fitur yang disesuaikan dengan kebutuhan Puskesmas dan juga masyarakat desa terutama para ibu yang memiliki bayi usia dibawah 1 tahun.

\section{KESIMPULAN}

Kegiatan pengabdian kepada masyarakat ini sudah terlaksana dengan sangat baik. Sistem imunisasi online sudah diimplementasi, sudah dilakukan pelatihan terhadap para pengguna sistem dan sosialisasi sistem juga sudah dilakukan ke masyarakat di desa Lengkong Kulon. Tujuan kegiatan sudah terlaksana sehingga manfaat kegiatan akan dapat dirasakan oleh pihak Puskesmas dan masyarakat Desa Lengkong Kulon, khususnya para ibu yang memiliki bayi berusia dibawah 1 tahun.

\section{UCAPAN TERIMAKASIH}

Ucapan terima kasih diberikan kepada Pihak Puskesmas Pegedangan yang telah bersedia menjadi mitra dalam kegiatan PKM ini. Dan juga kepada RISTEKDIKTI yang telah mensponsori kegiatan PKM ini.

\section{REFERENSI}

A. Cindana, F.N. Ferdinand (2017). Designing The Model of Online Immunization Record System, International Journal of Computer Science and Engineering (IJCSE), Vol 6 No.4., pp 21-30

Cormick, G., Ciganda, A., Cafferata, M., Ripple, M., Sosa-Estani, S., Buekens, P., Belizán, J. and Althabe, F. (2015). Text message interventions for follow up of infants born to mothers positive for Chagas disease in Tucumán, Argentina: a feasibility study. BMC Research Notes, 8 (1) 